\title{
PENGARUH METODE PEMBELAJARAN DAN MINAT BELAJAR TERHADAP HASIL BELAJAR IPA
}

\author{
EFFIYATI PRIHATINI \\ rizkiamandiri@gmail.com \\ Universitas Indraprasta PGRI Jakarta \\ Jl. Nangka 58. Tanjung Barat (TB Simatupang) Jagakarsa, Jakarta Selatan \\ http://www.unindra.ac.id
}

\begin{abstract}
Abstrak. Tujuan penelitian ini untuk mengetahui pengaruh metode pembelajaran terhadap penguasaan konsep IPA. Untuk mengetahui pengaruh minat belajar siswa terhadap penguasaan konsep IPA. Untuk mengetahui pengaruh interaktif metode pembelajaran dan minat belajar siswa terhadap penguasaan konsep IPA. Metode penelitian yang digunakan adalah metode Quasi eksperimen dengan pendekatan Kuantitatif. Penelitian dilaksanakan di Mts Negeri 1 Jakarta Selatan dan Mts N 23 Jakarta Selatan pada tahun ajaran 2016/2017. Sampel dalam penelitian ini berjumlah 70 siswa dengan random sampling. Pengujian hipotesis dengan ANOVA 2 arah. Hasil penelitian menunjukan terdapat pengaruh yang signifikan penggunaan media pembelajaran terhadap hasil belajar IPA, terdapat pengaruh yang signifikan minat belajar terhadap hasil belajar IPA, terdapat pengaruh yang tidak signifikan interaksi metode pembelajaran dan minat belajar terhadap hasil belajar IPA.
\end{abstract}

Kata Kunci: Metode Pembelajaran, Minat Belajar dan Hasil Belajar IPA.

\begin{abstract}
The purpose of this study to determine the effect of learning methods on the mastery of the concept of science. To know the influence of student's learning interest to mastery of science concept. To know the influence of interactive learning method and student's interest to the mastery of science concept. The research method used was Quasi experimental method with Quantitative approach. The research was conducted in Mts Negeri 1 South Jakarta and Mts N 23 South Jakarta in the academic year 2016/2017. The sample in this study amounted to 70 students with random sampling. Hypothesis testing with 2 way ANOVA. The result of the research shows that there is a significant influence of the use of learning media to the learning outcomes of science, there is a significant influence of learning interest on the learning outcomes of science, there is a nonsignificant influence of the interaction of learning methods and the interest of learning on the science learning outcomes.
\end{abstract}

Keywords: learning method, learning interest and science learning outcomes.

\section{PENDAHULUAN}

Pendidikan sebagai proses memproduksi sistem nilai dan budaya kearah yang lebih baik, antara lain dalam pembentukan kepribadian, keterampilan dan perkembangan intelektual siswa. Dalam lembaga formal proses reproduksi sistem nilai dan budaya ini dilakukan terutama dengan mediasi proses belajar mengajar sejumlah mata pelajaran di kelas.

Materi pembelajaran IPA mencakup konsep-konsep dasar, pendekatan, metode, dan teknik analisis ilmiah dalam pengajian berbagai fenomena dan permasalahan yang ditemui dalam kehidupan nyata di masyarakat.Mata pelajaran IPA dianggap sebagai suatu mata pelajaran yang sulit dipahami oleh siswa sehingga mengurangi minat mereka dalam mempelajarinya. 
Menurut pengamatan penulis selama menjadi guru di Sekolah Menengah Pertama (SMP) di Jakarta selama hampir tiga dekade, siswa menganggap bahwa mata pelajaran IPA merupakan salah satu mata pelajaran yang kurang disukai atau kurang diminati. Sebagian besar siswa belum mencapai prestasi hasil belajar maksimal dalam pelajaran IPA karena membosankan dan sajiannya banyak rumus dan hitungan. Hal itu dapat dilihat pada nilai perolehan siswa dalam Ulangan Harian (UH), Ulangan Tengah Semester (UTS), Ulangan Akhir Semester (UAS), bahkan dalam Ujian nasional (UN) yang masih belum memenuhi KKM (kriteria ketuntasan minimal).

KKM sekolah ditentukan oleh sekolah masing-masing sesuai dengan situasi dan kondisi sekolah. Sekolah dengan standar kualifikasi berbeda tentu berbeda pula standar KKM-nya. Walau demikian banyak juga siswa menganggap mata pelajaran IPA itu menyenangkan, misalnya tidak sedikit siswa yang mengaku bahwa setelah mempelajari IPA mereka memahami konsep dan manfaat nya bagi kehidupan mereka kini dan nanti karena belajar IPA banyak tantangannya semisal dalam praktek/percobaan di laboratorium siswa dilatih untuk melaksanakannya dengan metode ilmiah,tidak sembarang mengerjakan.

Mulai dari mempersiapkan alat dan bahan.melaksanakan percobaan,mencatat data hasil percobaan sampai pada merangkum dan membuat simpulan percobaan dilakukan dengan hati-hati, teliti, jujur, disiplin, akurat, ulet dan tidak putus asa. Dalam praktek/percobaan belum tentu akan diperoleh hasil sesuai dengan yang diharapkan atau yang sesuai dengan teori yang ada bahkan seringkali hasil yang didapat meleset dari teori yang dipelajari seharusnya.Untuk mencapai hasil yang maksimal siswa akan berusaha terus dengan bimbingan guru serta dari berbagai sumber sampai mendapatkannya. Pengalaman ini akan membuat siswa menjadi seorang yang berkarakter seperti yang disebutkan dan diharapkan di atas untuk masa depan dalam kehidupannya dimasyarakat kelak.

Apalagi dalam era informasi teknologi (IT) atau teknologi informasi (TI ) seperti sekarang ini, IPA saling menunjang dengan kemajuan Informasi teknologi ( IT) tersebut., sehingga semakin terbukalah akses kemajuan pendidikan secara umum dan pendidikan IPA khususnya, yang kemudian diharapkan menghasilkan seseorang atau siswa yang senang dan berminat tinggi terhadap mata pelajaran IPA. Dengan demikian maka sumber pembelajaran tidak hanya terfokus pada guru seperti selama ini akan tetapi Internet / teknologi informasi (IT) dapat merupakan alternatif sumber belajar lain yang sangat menunjang.

Profesionalitas guru dalam memilih dan menggunakan metode pembelajaran yang sesuai dengan tema atau pokok bahasan serta dengan memperhatikan minat belajar yang terdapat pada siswa selain factor -faktor lainnya juga memiliki peran yang tidak kalah penting dalam usaha mengubah hasil belajar IPA siswa yang semula rendah atau dibawah KKM sehingga dapat diusahakan meningkat semaksimal mungkin melampaui KKM.

Untuk mengubah hasil belajar siswa tersebut, seorang guru harus memiliki pengetahuan yang mendalam tentang materi-materi yang akan disampaikan serta mampu mengolah materi dan tepat dalam menggunakan metode pembelajaran menurut Paikem (Pembelajatan aktif,inovatif,kreatif dan menyenangkan ) dan tidak kalah penting untuk memperhatikan minat sebagai salah satu faktor penunjang keberhasilan suatu pembelajaran IPA yang hendak dicapai.

Seorang guru juga harus memiliki strategi belajar mengajar yang tepat, sehingga proses pembelajaran dapat berjalan dengan baik, salah satu di antaranya adalah pemilihan dan penggunaan metode pembelajaran diskusi dalam proses pembelajaran.Penulis berpendapat bahwa penyajian materi, pemilihan metode diskusi dalam proses pembelajaran IPA sangat penting dalam menarik minat dan perhatian siswa. Metode 
pembelajaran berfungsi sebagai salah satu penunjang dan daya dukung terjadinya keefektifan proses pembelajaran, sehingga dapat menambah minat belajar serta mempermudah siswa dalam belajar yang pada akhirnya siswa mendapatkan hasil belajar yang memuaskan.

Minat seseorang terhadap pelajaran dapat dilihat dari kecenderungan untuk memberikan perhatian yang lebih besar terhadap pelajaran tersebut. Bila seseorang mempunyai minat yang besar terhadap pelajaran matematika maka nilai hasil belajarnya cenderung berubah ke arah yang lebih baik

\section{TINJAUAN PUSTAKA \\ Metode Pembelajaran}

Menurut Nana Sudjana (2005: 76), Metode pembelajaran ialah cara yang dipergunakan guru dalam mengadakan hubungan dengan siswa pada saat berlangsungnya pengajaran. Yang dimaksud disini bahwa metode merupakan sebuah cara yang digunakan guru mata pelajaran dalam menyampaikan materi ajar kepada siswanya. Metode pembelajaran tersebuat harus disesuaikan dengan kebutuhan dan pokok bahasan yang diajarkan.

Menurut M. Sobri Sutikno (2009: 88) menyatakan, "Metode pembelajaran adalah cara-cara menyajikan materi pelajaran yang dilakukan oleh pendidik agar terjadi proses pembelajaran pada diri siswa dalam upaya untuk mencapai tujuan. Tujuan yang hendak dicapai dalam proses pembelajaran tentu adalah tingkat keberhasilan dari pembelajaran tesebut.

Menurut Taniredja (2011:23) Diskusi adalah suatu proses penglihatan dua atau lebih individu yang berinteraksi secara verbal dan saling berhadapan muka mengenai tujuan atau sasaran yang sudah ditentukan melalui cara tukar menukar informasi, mempertahankan pendapat, atau pemecahan masalah. Sedangkan metode diskusi adalah suatu cara penyajian bahan pelajaran dimana guru memberi kesempatan kepada siswa (kelompokkelompok siswa) untuk mengadakan perbincangan ilmiah guna mengumpulkan pendapat, membuat kesimpulan, atau menyusun berbagai alternatif pemecahan atas suatu masalah.

Aqib (2014: 107) mengatakan metode diskusi merupakan interaksi antara siswa dengan siswa atau siswa dengan guru untuk menganalisis, memecahkan masalah, menggali, memperdebatkan topik atau permasalahan tertentu. Metode diskusi adalah cara penyajian pelajaran, dimana siswa dihadapkan kepada suatu masalah yang bisa berupa pernyataan atau pertanyaan yang bersifat problematik untuk dibahas dan dipecahkan bersama, sehingga terjadi interaksi antara dua atau lebih individu yang terlibat, saling tukar menukar pengalaman, informasi, memecahkan masalah.

\section{Minat Belajar}

Minat merupakan salah satu aspek psikis yang dapat mendorong manusia mencapai tujuan. Seseorang yang memiliki minat terhadap suatu objek, cenderung memberikan perhatian ata merasa senang yang lebih besar kepada objek tersebut. Namun, apabila objek tersebut tidak menimbulkan rasa senang, maka orang itu tidak akan memiliki minat atas objek tersebut. Oleh karena itu, tinggi rendahnya perhatian atau rasa senang seseorang terhadap objek dipengaruhi oleh tinggi rendahnya minat seseorang tersebut. Dengan demikian disimpulkan bahwa pengertian minat belajar adalah kecenderungan individu untuk memiliki rasa senang tanpa ada paksaan sehingga dapat menyebabkan perubahan pengetahuan, ketrampilan dan tingkah laku

Menurut Eti rohaeti (2005: 28), dalam membangkitkan minat siswa akan terdorong untuk belajar manakala mereka memilki minat untuk belajar. Oleh sebab itu, 
mengembangkan minat belajar siswa merupakan salah satu teknik dalam mengembangkan minat belajar.Dari penjelasan di atas dapat diambil kesimpulan bahwa minat belajar akan terdorong apabila bahan pelajaran mempunyai hubungan sesuai dengan kebutuhan mereka, melihat perkembangan, tingkat pengalaman dan kemampuan siswa, serta model dan metode pembelajaran yang variatif.

\section{Hasil Belajar IPA}

Menurut Slamento (2010: 18) Belajar merupakan kegiatan manusia yang berakal, pengetahuan, sikap dan keterampilan akan terbentuk, termodifikasi serta berkembang melalui proses belajar. Belajar adalah perubahan tingkah laku pada diri individu sebagai akibat dari pengalaman. Oleh karena itu seseorang dikatakan belajar bila didalam dirinya terjadi suatu proses kegiatan yang mengakibatkan perubahan tingkah laku. Perubahan tingkah laku ini disertai usaha, karena tanpa usaha tidak dapat dikatakan belajar.

Menurut Hamalik (2008: 5) Hasil belajar ialah sebagai terjadinya perubahan tingkah laku pada diri seseorang yang dapat di amati dan di ukur bentuk pengetahuan, sikap dan keterampilan. Perubahan tersebut dapat diartikan sebagai terjadinya peningkatan dan pengembangan yang lebih baik sebelumnya yang tidak tahu menjadi tahu. Dari penjelasan tersebut mengatakan bahwa hasil belajar merupakan implementasi dari sebuah proses belajar yang dilalui oleh seseorang.

Menurut Sudjana (2009: 3) hasil belajar siswa pada hakikatnya ialah perubahan tingkah laku sebagai hasil belajar dalam pengertian yang lebih luas mencakup bidang kognitif, afektif dan psikomotorik. Bentuk perubahan yang dimaksud tentunya adalah perubahan yang terjadi secara positif. Bidang-bidang atau aspek pendidikan yang ada dalam diri siswa harus dikemabangkan melalui proses belajar.

Asep Herry Hernawan, dkk (2008: 2.11) berpendapat "belajar diartikan sebagai suatu proses perubahan perilaku yang terjadi melalui pengalaman". Purwanto (2008: 3839) juga berpandangan bahwa "belajar merupakan proses dalam diri individu yang berinteraksi dengan lingkungan untuk mendapatkan perubahan dalam perilakunya".

Winkel dalam Hartadi (2012: 36) mengemukakan "belajar adalah suatu aktivitas mental atau psikis yang berlangsung dalam interaksi aktif dengan lingkungan, yang menghasilkan perubahan-perubahan dalam pengetahuan, pemahaman, ketrampilan, dan nilai sikap". Hasil belajar IPA adalah sebuah aktifitas belajar ilmu pengetahuan alam yang melalui proses pembelajaran teoritis dan praktikum, Kemudian Santrock dan Yussen (Sugihartono, dkk, 2007: 74) mendefinisikan belajar sebagai perubahan yang relatif permanen karena adanya pengalaman. Mengacu pendapat-pendapat para ahli tersebut tentang belajar tersebut dapat disimpulkan bahwa belajar adalah suatu proses agar siswa mengalami langsung, terlibat aktif dan beriteraksi dengan lingkungan untuk melakukan suatu perubahan atau meningkatkan kemampuan dalam hal pengetahuannya yang berlangsung secara terus menerus.

Selanjutnya Purwanto (2010: 44) berpendapat tentang hasil belajar bahwa "hasil belajar sering kali digunakan sebagai ukuran untuk mengetahui sejauh mana seseorang menguasai bahan yang sudah diajarkan". Pada pembahasan ini tentu pada Ilmu Pengetahuan Alam yang merupakan mata pelajaran yang dipelajari siswa sekolah menengah pertama.

\section{METODE}

Penelitian ini diadakan selama 3 bulan di MTs Negeri 23 Jakarta Selatan dan MTs Negeri 1 Jakarta Selatan. Penelitian dilakukan kepada 72 siswa yang terdiri dari 35 siswa dari MTs Negeri 23 Jakarta Selatan dan 35 siswa dari MTs Negeri 1 Jakarta Selatan. 
Penelitian ini merupakan penelitian eksperimen dengan 2 perlakuan yang berbeda dan survey. Sehingga dapat dikatakan penelitian Eksperimen by level. Dimana variabel (A) adalah metode Pembelajaran yang terdiri dari metode Diskusi (A1) dan Metode Konvensional (A2) dan variabel minat Belajar (B) yang dikelompokan dalam Minat Belajar Tinggi (B1) dan Minat Belajar rendah (B2).Desain penelitian dapat digambarkan sebagai berikut,

\begin{tabular}{|c|c|c|c|}
\hline \multirow{2}{*}{ Minat Belajar } & \multicolumn{2}{|c|}{ Metode Pembelajaran } & \multirow{2}{*}{$\Sigma$} \\
\cline { 2 - 3 } & $\begin{array}{c}\text { Diskusi } \\
\left(\mathrm{A}_{1}\right)\end{array}$ & $\begin{array}{c}\text { Konvensional } \\
(\mathrm{A} 2)\end{array}$ & \multirow{2}{*}{$\mathrm{A}_{1} \mathrm{~B}_{1}$} \\
\hline Tinggi $\left(\mathrm{B}_{1}\right)$ & $\mathrm{A}_{2} \mathrm{~B}_{1}$ & \\
\hline Rendah $\left(\mathrm{B}_{2}\right)$ & $\mathrm{A}_{1} \mathrm{~B}_{2}$ & $\mathrm{~A}_{2} \mathrm{~B}_{2}$ & \\
\hline$\Sigma \mathrm{K}$ & & & \\
\hline
\end{tabular}

\section{Gambar 1. Desain Factorial Penelitian}

Desain faktorial digunakan apabila ada dua atau lebih variabel dengan masingmasing variabel memiliki lebih dari satu situasi. Pada eksperimen ini tentang metode pembelajaran diskusi $\left(A_{1}\right)$, dan metode pembelajaran konvensional $\left(A_{2}\right)$, pada siswa dengan minat belajar tinggi $\left(B_{1}\right)$ dan siswa dengan minat belajar rendah $\left(B_{2}\right)$. Karena ada dua cara pada masing-masing variabel maka disebut dengan 2 X 2 factorial design

HASIL DAN PEMBAHASAN Analisis Deskriptif Data

Tabel 1. Deskriptif Data

\begin{tabular}{lrrrrrrrr}
\hline & A1 & \multicolumn{1}{c}{ A2 } & \multicolumn{1}{c}{ B1 } & \multicolumn{1}{c}{ B2 } & A1B1 & A1B2 & A2B1 & A2B2 \\
\hline Mean & 77,46 & 72,54 & 77,00 & 72,88 & 78,94 & 76,06 & 75,26 & 69,31 \\
Median & 78,00 & 75,00 & 75,00 & 74,50 & 80,00 & 78,00 & 75,00 & 70,00 \\
Mode & 85 & 75 & 75 & $65^{\mathrm{a}}$ & $75^{\mathrm{a}}$ & $80^{\mathrm{a}}$ & 75 & $65^{\mathrm{a}}$ \\
$\begin{array}{l}\text { Std. } \\
\text { Deviation }\end{array}$ & 8,988 & 7,217 & 7,830 & 8,700 & 9,679 & 8,314 & 5,404 & 7,905 \\
Variance & 80,785 & 52,079 & 61,314 & 75,683 & 93,684 & 69,114 & 29,205 & 62,496 \\
Skewness &,- 493 &,- 211 &,- 221 &,- 015 &,- 840 &,- 284 &, 485 &, 181 \\
$\begin{array}{l}\text { Std. Error } \\
\text { of }\end{array}$ &, 398 &, 398 &, 393 &, 403 &, 550 &, 536 &, 524 &, 564 \\
$\begin{array}{l}\text { Skewness } \\
\text { Kurtosis }\end{array}$ &,- 039 &, 179 &, 792 &,- 727 & 1,119 &,- 815 &,- 049 &, 011 \\
$\begin{array}{l}\text { Std. Error } \\
\text { of }\end{array}$ &, 778 &, 778 &, 768 &, 788 & 1,063 & 1,038 & 1,014 & 1,091 \\
Kurtosis & & & & & & & & \\
Minimum & 55 & 55 & 55 & 55 & 55 & 60 & 67 & 55 \\
Maximum & 95 & 86 & 95 & 90 & 95 & 90 & 85 & 86 \\
\hline
\end{tabular}


Persyaratan Analisis Data

Tabel 2. Uji Normalitas Data

\begin{tabular}{|c|c|c|c|c|c|c|c|c|c|}
\hline \multicolumn{2}{|l|}{$\mathbf{N}$} & A1 & $\mathbf{A 2}$ & B1 & $\mathbf{B 2}$ & $\begin{array}{c}\mathbf{A 1 B} \\
\mathbf{1} \\
17\end{array}$ & $\begin{array}{c}\mathbf{A 1 B} \\
\mathbf{2} \\
18\end{array}$ & $\begin{array}{c}\mathbf{A 2 B} \\
\mathbf{1} \\
19\end{array}$ & $\begin{array}{c}\mathbf{A 2 B} \\
\mathbf{2} \\
16\end{array}$ \\
\hline \multirow{4}{*}{$\begin{array}{l}\text { Normal } \\
\text { Parameters }\end{array}$} & Mean & 77,4 & 72,5 & 77,0 & 72,8 & 78,94 & 76,06 & 75,26 & 69,31 \\
\hline & & 6 & 4 & 0 & 8 & & & & \\
\hline & Std. & 8,98 & 7,21 & 7,83 & 8,70 & 9,679 & 8,314 & 5,404 & 7,905 \\
\hline & $\begin{array}{l}\text { Deviatio } \\
\mathrm{n}\end{array}$ & 8 & 7 & 0 & 0 & & & & \\
\hline \multirow{3}{*}{$\begin{array}{l}\text { Most } \\
\text { Extreme } \\
\text { Differences }\end{array}$} & Absolute & 114 & , 176 & ,149 &, 100 & , 165 &, 148 & , 183 & , 145 \\
\hline & Positive & ,086 & ,116 &, 134 & , 100 & ,091 &, 111 & , 183 & , 145 \\
\hline & Negative &,- 114 &,- 176 &,- 149 &,- 096 &,- 165 &,- 148 &,- 165 &,- 139 \\
\hline \multicolumn{2}{|c|}{ Kolmogorov-Smirnov Z } & ,672 & $\begin{array}{r}1,04 \\
2\end{array}$ &, 895 &, 585 & ,682 & ,628 & ,796 &, 579 \\
\hline \multicolumn{2}{|c|}{ Asymp. Sig. (2-tailed) } & 757 & ,228 & ,399 & ,883 & ,741 & ,825 & ,551 & 891 \\
\hline
\end{tabular}

Dari hasil pengujian menunjukan semua data berdistribusi normal

Tabel 3. Uji Homogenitas A1 dan A2

\begin{tabular}{cccc}
\hline $\mathrm{F}$ & df1 & df2 & Sig. \\
\hline 1,751 & 1 & 68 &, 190 \\
\hline
\end{tabular}

Dari hasil pengujian menunjukan kelompok A1 dan A2 homogen

Tabel 4. Uji Homogenitas B1 dan B2

\begin{tabular}{cccc}
\hline $\mathbf{F}$ & df1 & df2 & Sig. \\
\hline $\mathbf{1 , 3 1 1}$ & 1 & 68 &, 256 \\
\hline
\end{tabular}

Dari hasil pengujian menunjukan kelompok B1 dan B2 homogen

Tabel 5. Uji Homogenitas A1B1, A1B2, A2B1 DAN A2B2

\begin{tabular}{cccc}
\hline $\mathrm{F}$ & df1 & df2 & Sig. \\
\hline 2,255 & 3 & 66 &, 090 \\
\hline
\end{tabular}

Dari hasil pengujian menunjukan kelompok A1B1, A1B2, A2B1 dan A2 homogen 


\section{Pengujian Hipotesis Penelitian}

Tabel 6. Uji Hipoteis Penelitian

\begin{tabular}{lcrrrr}
\hline Source & $\begin{array}{l}\text { Type III } \\
\text { Sum of } \\
\text { Squares }\end{array}$ & df & $\begin{array}{c}\text { Mean } \\
\text { Square }\end{array}$ & F & Sig. \\
\hline $\begin{array}{l}\text { Corrected } \\
\text { Model }\end{array}$ & $802,993^{\mathrm{a}}$ & 3 & 267,664 & 4,270 &, 008 \\
Intercept & 391021,555 & 1 & 391021,555 & 6238,18 &, 000 \\
& & & & 6 & \\
A & 473,175 & 1 & 473,175 & 7,549 &, 008 \\
B & 340,201 & 1 & 340,201 & 5,427 &, 023 \\
A * B & 40,933 & 1 & 40,933 &, 653 &, 422 \\
Error & 4137,007 & 66 & 62,682 & & \\
Total & 398690,000 & 70 & & & \\
Corrected & 4940,000 & 69 & & & \\
Total & & & & & \\
\hline a. R Squared $=, 163$ (Adjusted R Squared =,124) & & & \\
\hline
\end{tabular}

Pengaruh metode pembelajaran terhadap hasil belajar IPA.

Hasil pengujian hipotesis pertama, diperoleh nilai sig $0,008<0,05$ dan $\mathrm{F}$ hitung $=$ $7,549>\mathrm{F}$ tabel $=2,231$ yang menunjukan bahwa terdapat pengaruh yang signifikan antara hasil belajar IPA siswa yang di ajar dengan metode diskusi dengan hasil belajar IPA siswa yang diajar dengan media konvensional. Hal ini didukung oleh perolehan rata-rata kelompok siswa yang diajar dengan metode diskusi sebesar 77,46 sedangkan rata-rata kelompok siswa yang diajar dengan media konvensional sebesar 72,54. Hal ini menunjukan bahwa nilai hasil belajar yang diajar dengan media diskusi lebih tinggin dari nilai pemahamana konsep IPA siswa yang diajar dengan media konvensional.

Berdasarkan hasil penelitian yang telah disampaikan Kurniadi (2010) menyatakan, diskusi kelompok/kelas dapat memberikan sumbangan yang berharga terhadap belajar siswa, antara lain. Membantu siswa untuk tiba kepada pengambilan keputusan yang lebih baik daripada memutuskan sendiri. Siswa tidak terjebak kepada jalan pemikiran sendiri yang kadang-kadang salah, penuh prasangka dan sempit. Diskusi kelompok/kelas memberi motifasi terhadap berfikir dan meningkatkan perhatian kelas terhadap apa yang sedang mereka pelajari. Diskusi juga membantu mengerahkan atau mendekatkan hubungan antara kegiatan kelas dengan tingkat perhatian dan derajat pengertian dari pada anggota kelas.

Untuk mencari suatu keputusan suatu masalah. Untuk menimbulkan kesanggupan pada siswa dalam merumuskan pikirannya secara teratur sehingga dapat diterima orang lain. Untuk membiasakan siswa mendengarkan pendapat orang lain sekalipun berbeda dengan pendapatnya sendiri, dan membiasakan sikap toleran.

Aqib (2014: 107) mengatakan metode diskusi merupakan interaksi antara siswa dengan siswa atau siswa dengan guru untuk menganalisis, memecahkan masalah, menggali, memperdebatkan topik atau permasalahan tertentu. Metode diskusi akan sangat cocok diterapkan untuk memecahkan masalah khususnya soal yang berupa study kasus.

Metode diskusi adalah cara penyajian pelajaran, dimana siswa dihadapkan kepada suatu masalah yang bisa berupa pernyataan atau pertanyaan yang bersifat problematik untuk dibahas dan dipecahkan bersama, sehingga terjadi interaksi antara dua atau lebih individu yang terlibat, saling tukar menukar pengalaman, informasi, memecahkan masalah (Djamarah, 2006: 99). Kelebihan metode diskusi antara lain. Menyadarkan anak 
didik bahwa masalah dapat dipecahkan dengan berbagai jalan dan bukan satu jalan. Menyadarkan anak didik bahwa dengan berdiskusi mereka saling mengemukakan pendapat secara konstruktif sehingga dapat diperoleh keputusan yang lebih baik. Membiasakan anak didik untuk mendengarkan pendapat orang lain sekalipun berbeda dengan pendapatnya sendiri dan membiasakan bersikap toleransi.

\section{Pengaruh minat belajar siswa terhadap hasil belajar IPA}

Hasil pengujian hipotesis kedua, diperoleh nilai sig. $=0,023<0,05$ dan $\mathrm{F}$ hitung $=$ $5,427>\mathrm{F}$ tabel $=2,231$ yang menunjukan bahwa terdapat pengaruh yang signifikan antara hasil belajar IPA siswa yang memiliki minat tinggi dan siswa yang memiliki minat rendahl. Hal ini didukung oleh perolehan rata-rata kelompok siswa yang diajar dengan media diskusi sebesar 77,00 sedangkan rata-rata kelompok siswa yang diajar dengan media konvensional sebesar 72,88 . Hal ini menunjukan bahwa nilai hasil belajar yang memiliki minat tinggi lebih baik dari hasil belajar IPA siswa yang memiliki minat rendah.

Minat adalah kemampuan untuk menghasilkan gagasan yang asli, artinya kemampuan mengutarakan ide-ide yang bersifat unik dan jarang terjadi, bila dibandingkan dengan cara orang lain merespon masalah yang sama. Ide asli adalah yang belum pernah dikemukakan orang lain dan sifatnya baru.

Lebih lanjut dijelaskan Sumarjadi (2010: 2) bahwa orang yang terampil dalam suatu bidang tidak ragu-ragu dalam melakukan pekerjaan tersebut, seolah-olah sudah tidak dipikirkan lagi bagaimana pelaksanaanya. Tidak ada lagi kesulitan yang menghambat. Dalam ruang lingkup yang lebih luas, minat merupakan kegiatan berupa pembuatan, berpikir, berbicara, melihat, mendengar, dan sebagainya. Sedangkan dalam pengertian yang sempit biasanya minat ditunjukan dalam perbuatan.

Menurut Munandar yang diterjemahkan Sukmadinata (2004:104): Minat adalah kemampuan a) untuk membuat kombinasi baru berdasarkan data informasi atau unsur yang ada, b) berdasarkan data atau informasi yang tersedia, menemukan banyak kemungkinan jawaban terhadap suatu masalah, dimana penekanannya adalah pada kualitas, ketepat gunaan dan keragaman jawaban, c) yang mencerminkan kelancaran, keluwesan dan orisinilitas dalam berfikir serta kemampuan untuk mengelaborasi suatu gagasan. Sehingga dapat jelas dikatakan bahawa minat belajar seseorang sangatlah penting dalam menunjang keberhasilan belajar siswa. Khususnya dalam penelitian ini bahwa semakin tinggi tingkat minat belajar siswa maka kemampuan hasil belajar IPA yang dimiliki siswa tersebut juga tinggi.

Menurut komite Penasehat Nasional bidang pendidikan diskusi dan pendidikan budaya yang diterjemahkan oleh Craft (2005:291), "Menggambarkan minat sebagai bentuk aktivitas imajinatif yang mampu menghasilkan sesuatu yang bersifat original, murni, asli, dan memiliki nilai". Dari uraian di atas dapat disimpulkan bahwa minat belajar adalah suatu kondisi, sikap, kemampuan, dan proses perubahan tingkah laku seseorang untuk menghasilkan produk atau gagasan, mencari pemecahan masalah yang lebih efisien dan unik dalam proses belajar.

\section{Pengaruh interaksi metode pembelajaran dan minat belajar siswa terhadap hasil belajar IPA.}

Hasil pengujian hipotesis ketiga, diperoleh nilai sig. $=0,422>0,05$ dan $\mathrm{F}$ hitung $=$ $0,653<\mathrm{F}$ tabel $=2,231$ yang menunjukan bahwa terdapat pengaruh interaksi yang tidak signifikan metode pembelajaran dan minat belajar siswa terhadap hasil belajar IPA.

Menurut Hurlock (2005:11) beberapa kegiatan untuk meningkatkan minat adalah: 1) Waktu 2) Kesempatan 3) Dorongan 4) Sarana 5) Lingkungan 6) Hubungan dengan orang tua 7) Cara mendidik anak 8) Pengetahuan. Minat tidak hanya tergantung pada 
potensi bawaan yang khusus, tetapi juga pada perbedaan mekanisme mental atau sikap mental yang menjadi sarana untuk mengungkapkan sikap bawaan tersebut. Selanjutnya untuk melengkapi uraian mengenai faktor yang mempengaruhi minat tentang minat, perlu dikemukakan adanya beberapa indikator minat.

Menurut Uno (2010:21) indikator minat sebagai berikut: 1) Memiliki rasa ingin tahu yang besar 2) Sering mengajukan pertanyaan yang berbobot 3) Memberikan banyak gagasan dan usul terhadap suatu masalah 4) Mampu menyatakan pendapat secara spontan dan tidak malu-malu 5) Mempunyai atau menghargai keindahan 6) Mempunyai pendapat sendiri dan dapat mengungkapkannya, tidak mudah terpengaruh orang lain. 7) Memiliki rasa humor tinggi 8) Mempunyai daya imajinasi yang kuat 9) Mampu mengajukan pemikiran, gagasan pemecahan masalah yang berbeda dari orang lain (orisinil) 10) Dapat bekerja sendiri 11) Senang mencoba hal-hal baru 12) Mampu mengembangkan atau merinci suatu gagasan (kemampuan elaborasi)

Dengan memanfaatkan metode pembelajaran diskusi maka akan meningkatkan minat siswa dalam belajar, sehingga dapat meningkatkan kemampuan siswa dalam memahami semua konsep pembelajaran khusus nya pembelajaran IPA. Dengan meningkatnya hasil belajar IPA membuat siswa menjadi lebih mandiri dan dapat meraih prestasi belajar yang bail pula.

\section{DAFTAR PUSTAKA}

Ana Craft. 2005. Membangun Kreativitas Anak. Depok: Insani Press.

Aqib, Zainal. 2014. Model-model, Media, dan Strategi Pembelajaran Kontekstual (Inovatif). Bandung: Yrama Widya.

Asep Hermawan. 2008. Penelitian Bisnis Paradigma Kuantitatif. Jakarta: PT Grasindo. Djamarah. 2006. Psikologi Belajar. Jakarta: Rineka Cipta.

Dr. M. Sobry Sutikno. 2009. Belajar dan Pembelajaran. Bandung: Prospect.

Hamalik, O. 2008. Kurikulum dan Pembelajaran. Jakarta: PT. Bumi Aksara.

Hartadi, Bambang. 2012. Pengaruh fee audit, rotasi kap, dan reputasi auditor terhadap kualitas audit di Bursa Efek Indonesia. Jurnal Ekonomi dan Keuangan, 16 (1), 84-103.

Hurlock, E.B. 2005. Perkembangan Anak (jilid 1). Jakarta: Erlangga.

Kurniadi, H. 2010. Strategi Pembelajaran Inquiri Sosial. Tersedia di http://www.papantulisku.com/. Diakses pada tanggal 25 Agustus 2017.

Sukmadinata, N.S. 2004. Landasan Psikologi Proses Pendidikan. Bandung: PT. Remaja Rosdakarya.

Purwanto. 2010. Evaluasi Hasil Belajar. Yogyakarta: Pustaka Pelajar.

Rohaiti. 2005. Sistem Informasi Manajemen Pendidikan. Jakarta: Bumi aksara.

Slameto. 2010. Belajar dan Faktor-faktor yang Mempengaruhinya. Jakarta: Rineka Cipta.

Soemarjadi, Muzni dan Wikdati. 2010. Pendidikan Keterampilan. Departemen Pendidikan dan Kebudayaan Direktorat Jenderal Pendidikan Tinggi Proyek Pembinaan Tenaga Kependidikan.

Sudjana, N. 2005. Dasar-Dasar Belajar Mengajar. Bandung: Sinar Baru Algensindo.

Sudjana. 2009. Penilaian Hasil Proses Belajar Mengajar. Bandung: PT Remaja Rosdakarya.

Sugihartono. 2007. Psikologi Pendidikan. Yogyakarta: UNY Press.

Taniredja, T. 2011. Model-Model Pengembangan Inovatif. Bandung: Alfabeta.

Uno, H. 2010. Perencanaan Pembelajaran. Jakarta: Bumi Aksara. 